\title{
Clinical correlations of SARS-CoV-2 antibody responses in patients with COVID-19 infection
}

DeSimone, Mia, M.D., M.P.H. ${ }^{1, \#, ~ S i m m o n s, ~ D a i m o n ~ P, ~ M . D . ~ P h . D . ~}{ }^{1, \#,}$, Tolan, Nicole, Ph.D. ${ }^{1}$, Melanson, Stacy, M.D. Ph.D. ${ }^{1}$, Petrides, Athena, Ph.D. ${ }^{1}$, Tanasijevic, Milenko, M.D. M.B.A. ${ }^{1}$, Schur, Peter, M.D. FACP2*

${ }^{1}$ Department of Pathology, Brigham and Women's Hospital, Boston, MA 02115

${ }^{2}$ Division of Rheumatology, Department of Medicine, Brigham and Women's Hospital, Boston, MA 02115

${ }^{\#}$ Co-first authors

${ }^{*}$ Corresponding author:

Peter H. Schur, M.D.

Brigham and Women's Hospital and Harvard Medical School

75 Francis Street, Boston, MA 02115

pschur@bwh.harvard.edu 


\begin{abstract}
Coronavirus disease 19 (COVID-19) is caused by the severe acute respiratory syndrome
\end{abstract} coronavirus 2 (SARS-CoV-2). Understanding the clinical correlations of antibodies produced by infected individuals will be critical for incorporating antibody results into clinical management. This study was an observational cohort study to evaluate antibody responses in individuals with PCR-confirmed COVID-19, including 48 hospitalized patients diagnosed with COVID-19 by realtime polymerase chain reaction (RT-PCR) at a large tertiary care medical center. Serum samples were obtained from patients at various time points during the disease course and tested for $\operatorname{lgM}$ and IgG antibodies against SARS-CoV-2. Medical records were reviewed, and antibody levels were compared with clinical and laboratory findings. Patients did not have high levels of antibodies within one week of symptoms, but most had detectable IgM and IgG antibodies between 8 and 29 days after onset of symptoms. Some individuals did not develop measurable levels of IgM or IgG antibodies. IgM antibodies were associated with elevated ALT, but there were no other significant associations. We did not observe significant associations of SARS-CoV2 antibodies with clinical outcomes, including intubation and death. SARS-CoV-2 IgM and IgG antibodies were unlikely to be detected in the first week of infection or in severely immunocompromised individuals. Although we did not observe associations with clinical outcomes, IgM antibodies were associated with higher ALT levels. Antibody production reflects the virus-specific immune response, which is important for immunity but also drives pathology, and antibody levels may be important for guiding treatment of individuals with COVID-19. 


\section{Introduction}

Coronavirus disease 19 (COVID-19) is caused by the severe acute respiratory syndrome coronavirus 2 (SARS-Cov-2) and is currently leading to a major global pandemic after originating in Wuhan, China in late 2019. ${ }^{1-11}$ Individuals infected with this virus have a range of symptoms including cough, difficulty breathing, fever, chills, muscle pain, headache, sore throat, loss of smell or taste, and gastrointestinal symptoms. ${ }^{1,5-15}$ Many individuals with COVID-19 are asymptomatic or report mild symptoms but others, especially those of advanced age with underlying comorbidities, can become critically ill with respiratory failure, septic shock, and/or multiorgan dysfunction or failure..$^{5-8,10-12,14-16}$ Although immune responses are critical for protection against the virus, significant mortality results from immune activation and cytokine storm, and immune suppression may paradoxically play a critical role in the treatment of patients with complications from excess immune activation. ${ }^{17,18}$

SARS-CoV-2 is an enveloped, single-stranded RNA virus of the family Coronaviridae that contains four structural glycoproteins: envelope (E), membrane (M), nucleocapsid $(N)$, and spike (S). ${ }^{3,4}$ Detection of SARS-CoV-2 viral RNA by reverse transcriptase-polymerase chain reaction (RT-PCR) in samples collected from nasopharyngeal swabs or saliva is the gold standard diagnostic test to confirm early infection..$^{7,8,15,19}$ The sensitivity of these diagnostic tests is limited by the adequacy of the sample collection, and viral RNA may only be detectable during the acute phase of infection. ${ }^{15,19,20}$ Detection of antibodies may further elucidate the immune status of infected individuals ${ }^{20-26}$ and improve the sensitivity of identifying patients 
with COVID-19. ${ }^{21}$ In severe acute respiratory syndrome (SARS), virus-specific antibodies were detectable in $80-100 \%$ of patients two to three weeks after symptom onset. ${ }^{27-29}$ Initial reports have suggested that SARS-CoV-2-specific IgM is detectable in the acute phase and within one to two weeks of infection, whereas virus-specific IgG takes two to four weeks to become detectable during the recovery phase..$^{20-26,30}$ Many assays have become available to detect antibodies against SARS-CoV-2, ${ }^{31}$ with differing sensitivity and specificity. ${ }^{32,33}$

Patients may develop neutralizing antibodies against SARS-CoV-2 that will be important for

immunity. ${ }^{34,35}$ However, higher viral-specific antibody levels have also been associated with a worse clinical prognosis. ${ }^{21}$ Consistent with this discrepancy, in animal models of infection with other related coronaviruses, antibodies contribute to inflammation and pathology, ${ }^{36-39}$ and immune activation is an important consideration for SARS-CoV-2. ${ }^{40}$ The balance of protection and inflammation driven by specific antibodies to SARS-CoV-2 is not yet well understood. To address this gap in knowledge, we performed a detailed analysis of serological and clinical results for a cross-section of patients in a large tertiary academic medical center during the COVID-19 pandemic.

\section{Methods}

\section{$\underline{\text { Patient Selection }}$}

Samples were collected as discarded specimens from routine clinical care of forty-eight patients diagnosed with COVID-19 and hospitalized at Brigham and Women's Hospital in Boston, MA 
from April 3 to April 17, 2020. Patients with COVID-19 were identified based on a previous positive lab result for SARS-CoV-2 nucleic acid by RT-PCR using nasopharyngeal swab samples. There were no other specific inclusion or exclusion criteria. Many patients were discharged shortly after initial diagnosis, and serial serum samples were obtained from 17 patients over this 14-day period. Medical records were reviewed for past medical history, date of illness onset, presenting symptoms, hospital length of stay, and outcome. Laboratory values were extracted if available within 48 hours of the corresponding serum sample used for this analysis.

\section{$\underline{\text { Reagents/Antibody Measurement }}$}

$\operatorname{lgM}$ and IgG antibodies against SARS-CoV-2 were detected in serum samples using enzymelinked immunosorbent assay (ELISA) kits (Epitope Diagnostics, San Diego, CA) and performed according to the manufacturer's instructions. This assay uses nucleocapsid antigens to detect IgM and IgG antibodies that bind SARS-CoV-2. The manufacturer's reported sensitivity is $98.4 \%$ for IgG and $73.8 \%$ for IgM. The manufacturer's reported specificity is $99.8 \%$ for IgG and $100 \%$ for IgM. This assay had similar performance in our clinical validation and in additional studies performed in our lab. ${ }^{41}$ Arbitrary units for SARS-CoV-2 IgM and IgG were calculated based on the optical density of the sample normalized to the positive cut-off defined by the optical density of the negative control. The positive cut-off was set to a value of 1 , and samples with units between 0.82 and 1 were reported as borderline. For our analysis, borderline results were treated as negative. 


\section{Data Analysis}

The last sample for patients with serial samples was selected for analysis of unique patients.

Nonparametric statistical analysis (Mann-Whitney) was used for laboratory findings, with values at the minimum or maximum measurements counted as ties. Patients with unavailable data for a laboratory test were excluded from the analysis for that test, as indicated in the table.

Graphical and statistical analysis was performed in Microsoft Excel 16.36 (Microsoft) and Prism 6.0.h (GraphPad). P.S., N.T., S.M., A.P., M.T., D.P.S., and M.D participated in study design, interpretation, and writing. Data analysis was performed by D.P.S. and M.D.

\section{Ethical Considerations}

This study was reviewed and approved by the Brigham and Women's Hospital Institutional Review Board (Boston, MA, USA).

\section{Results}

\section{$\underline{\text { Patient Characteristics }}$}

In order to study antibody responses to SARS-CoV-2, we identified 48 hospitalized patients at our institution who had at least one previous positive SARS-CoV-2 RT-PCR test and serum for additional testing. Serum samples were collected over the course of two weeks (April 3 to April $17,2020)$ to provide a cross-section of the SARS-CoV-2 serology responses within the hospital. The cohort of patients included in the study were individuals with diverse demographics, 
presenting symptoms, and comorbidities (Table 1). This cohort included a broad spectrum of individuals within the hospital: $52 \%$ women and $48 \%$ men from a variety of races and ethnicities, including 48\% Black or African American, 29\% Hispanic or Latino, and 27\% White. Comorbidities were present in the vast majority (92\%) of patients, with a high prevalence of hypertension (48\%), prior or current malignancy (29\%), and diabetes (27\%). Patients reported a wide range of symptoms that led them to first present to our institution for medical attention. All but two individuals in this cohort (96\%) endorsed more than one presenting symptom. Cough (81\%), fever (73\%), and shortness of breath (58\%) were commonly reported by these individuals.

High levels of SARS-CoV-2 IgM and IgG antibodies detected in a subset of patients

We evaluated IgM and IgG antibody responses to SARS-CoV-2 in patients over the course of infection based on reported onset of symptoms extracted from the medical record (median 14 days, interquartile range 11-18 days). We did not detect high levels of IgM or IgG antibodies in any samples collected from patients within the first seven days of infection (Fig 1A-B). The highest IgM levels (greater than 10 units) were detected from 10 to 16 days after onset of symptoms (Fig 1A). In contrast, a wide range of IgG levels were measured throughout the course of infection, including positive results from 8 to 29 days after onset of symptoms (Fig 1B). In addition, nine individuals did not develop high IgM or IgG antibodies against SARS-CoV-2 within this time frame. We analyzed serial samples to determine whether this finding might be due to rising or falling levels of IgM and IgG over time. IgM levels rose in six patients at early 
time points and were stable at later time points (Fig 1C). In contrast, samples from eleven patients collected over various time points showed increasing levels of IgG antibody (Fig 1D).

To control for the subjective nature of symptom reporting, we analyzed antibody results relative to the date of the first positive SARS-CoV-2 RT-PCR result, as a secondary measure of the time of acute infection. The highest IgM levels (greater than 10 units) were detected within 10 days (median 7 days, interquartile range 6-8 days) from the first positive SARS-CoV-2 RT-PCR, with very low levels detected at later time points (Fig 2A). In contrast, IgG levels varied over time relative to the first positive SARS-CoV-2 RT-PCR result (median 5 days, interquartile range 2-8 days) (Fig 2B). In the analysis of serial samples, IgM levels rose within the first week after a positive SARS-CoV-2 RT-PCR result and remained stable at later time points (Fig 2C). Similarly, IgG levels for all but one of the patients rose within the first week after the first positive SARSCoV-2 RT-PCR result, and three patients had stable levels of IgG more than 15 days after the positive RT-PCR (Fig 2D). Notably, nine individuals had persistently low levels of IgM and IgG antibodies, even long after initial infection defined both by symptoms and by detection of viral RNA.

Characteristics of patients with very low levels of SARS-CoV-2 IgM and IgG antibodies

We performed detailed chart reviews to identify clinical findings of patients who did not develop high levels of IgM or IgG antibodies against SARS-CoV-2 (Table 2). Samples from two individuals were collected less than one week after reported onset of symptoms, and it is 
possible that upon subsequent testing, antibodies would have been identified. Antibodies were also not detected in samples from three additional patients collected within two weeks of reported onset of symptoms. Although the low antibody levels could be attributed to early sample collection for six patients, two individuals did not produce high levels of SARS-CoV-2 antibodies even later in the course of infection. One individual with B cell acute lymphoblastic leukemia developed cough and headache while hospitalized for induction chemotherapy. This patient tested positive for SARS-CoV-2 by RT-PCR but did not develop SARS-CoV-2 antibodies as late as 19 days after onset of symptoms. Another patient with acute myeloid leukemia was admitted to the hospital with neutropenic fever and found to be positive for SARS-CoV-2 by RTPCR but had undetectable levels of SARS-CoV-2 antibodies as far out as 20 days from onset of symptoms. In contrast, five patients on immunosuppressive therapies did develop IgG antibodies, of which three also had IgM antibodies. including a patient post-transplant for myelofibrosis, on ruxolitinib and prednisone. Two patients produced SARS-CoV-2 antibodies despite a recent history of chemotherapy (alectinib, high-dose cytarabine, and etoposide for one patient, carboplatin/gemcitabine for another). Another patient with detectable SARS-CoV-2 antibodies was started on prednisone while in the hospital. These data indicate that, even with immunosuppressive medications, most hospitalized patients will develop antibodies against SARS-CoV-2 unless they are profoundly immunosuppressed. 
In order to identify other correlates of antibody responses, we evaluated the association of SARS-CoV-2 antibodies with other laboratory findings. We analyzed other laboratory results for patients with $(n=30)$ or without $(n=18)$ SARS-CoV-2 IgM antibodies (Table 3). The individuals without IgM antibodies were 61\% female, 33\% Black or African American, 33\% Hispanic or Latino, and $28 \%$ White, compared to $47 \%$ female, 33\% Black or African American, $27 \%$ Hispanic or Latino, and $27 \%$ White in the group positive for IgM antibodies. The median age was 65 (interquartile range 54-71 years) among IgM-negative individuals and 52 (interquartile range 47-67 years) among IgM-positive individuals. Individuals with IgM had higher ALT levels (Table 3). We did not observe an association between lymphocyte count and IgM levels. We also did not find significant associations of SARS-CoV-2 IgM antibodies with AST, globulin, troponin, ferritin, D-dimer, procalcitonin, or platelet count levels. The hospital stay was shorter for IgMpositive individuals (median 8 days, interquartile range 5.5-18.5 days) than IgM-negative individuals (median 13 days, interquartile range 4-24 days). The rate of intubation was 56\% $(n=10)$ in IgM-negative individuals versus $50 \%(n=15)$ in those with detectable IgM antibodies. The rate of death was $17 \%(n=3)$ in the IgM-negative group versus $13 \%(n=4)$ in the IgM-positive group for the duration of this study.

We performed a similar analysis of laboratory results for patients with $(n=39)$ or without $(n=9)$ SARS-CoV-2 IgG antibodies (Table 4). Individuals without IgG antibodies were $67 \%$ female, $33 \%$ Black or African American, 33\% Hispanic or Latino, and 22\% White. Those with IgG antibodies were $49 \%$ female, 33\% Black or African American, $28 \%$ Hispanic or Latino, and $28 \%$ White. The median age was 64 (interquartile range 55-71 years) for IgG-negative individuals and 54 
(interquartile range 47-69 years) for IgG-positive individuals. There were no significant associations of laboratory results with IgG levels, although there was a trend towards higher ALT, globulin, and D-dimer levels that was not statistically significant after correcting for multiple comparisons (Table 4). The hospital stay was shorter for IgG-positive individuals (median 8 days, interquartile range 5.25-18.75 days) compared with IgG-negative individuals (median 20 days, interquartile range8.5-28 days). The rate of intubation was $56 \%(n=5)$ among IgG-negative individuals and 51\% ( $n=20)$ among lgG-positive individuals. There was one fatality (11\%) among the patients without IgG antibodies and six fatalities (15\%) among the patients with detectable IgG antibodies for the duration of this study.

\section{Discussion}

In this study of hospitalized patients infected with SARS-CoV-2, we found that most patients had detectable SARS-CoV-2 IgM and IgG antibodies after a week following symptom onset, ranging from 8 to 29 days. Importantly, we only detected very low levels of IgM or IgG within the first week of infection. In this cohort of patients with confirmed COVID-19, nine out of fortyeight individuals did not produce high levels of IgM during the course of infection. This pattern might represent a less robust early immune response by individuals with modest symptoms. Thirty-nine out of forty-eight individuals developed IgG antibodies against SARS-CoV-2. The fact that we observed IgG antibodies more frequently than IgM might suggest a key role for helper T cells in generating antibody responses at later time points in infection. However, we did observe a modest association of IgM antibodies with elevated ALT enzymes. In addition to 
helping diagnose acute infection, high levels of IgM may represent a phase of the acute immune activation that can lead to disease pathology.

Although low antibody levels could be attributed to sampling early in the course of infection for some individuals, others did not have elevated antibodies even at later time points. Three severely immunocompromised individuals did not produce antibody responses, and this is an important consideration in immunocompromised patients for both diagnosis and monitoring potential protective immunity to future infection. Although these three severely immunocompromised patients did not produce high levels of antibodies, five individuals receiving immunosuppressive medications did have detectable IgG and/or IgM antibodies. This discrepancy might be explained by differences in the timing of immunosuppression or could represent alternative functions of different classes of immunosuppressive medications. Although immunosuppressed individuals are at risk for not developing antibodies against SARSCoV-2, many will develop antibodies unless profoundly immunosuppressed. This assay measures nucleocapsid antibodies, whereas antibodies against the receptor binding domain of the spike protein have been correlated with viral neutralization. ${ }^{34,35}$ However, it is currently unclear whether SARS-CoV-2 antibodies confer immunity, ${ }^{35}$ and if so, what titers against different viral antigens would be necessary. Additional studies will be essential to address this question. 
This study provides new information about antibody responses to SARS-CoV-2 in a U.S.

population, with important clinical information about individuals who do not develop high

levels of SARS-CoV-2 IgM or IgG antibodies. However, this study centers on a small population focused at a single tertiary care, large academic medical center and is based on the experience with a single serology assay. Very few individuals remained hospitalized at later time points in infection, so it was not feasible to obtain a large number of samples from late time points. Lack of follow-up after discharge limits the ability to identify possible correlations with long-term morbidity. Furthermore, other serology assays may feature improved sensitivity, particularly in the early detection of SARS-CoV-2 antibodies. Additional studies with larger numbers of patients and multiple centers will be necessary to more definitively determine the clinical status of patients with low and high levels of SARS-CoV-2 IgM and IgG antibodies and to better define how these antibody levels relate to clinical outcomes.

\section{Acknowledgments}

We thank Lisa Bernhard and Annmarie Anderson for testing samples, and Mike Conrad for assistance identifying samples.

\section{References}

1. Chan JFW, Yuan S, Kok KH, et al. A familial cluster of pneumonia associated with the 2019 novel coronavirus indicating person-to-person transmission: a study of a family cluster. Lancet. 2020;395(10223):514-523. doi:10.1016/S0140-6736(20)30154-9 
2. Zhu N, Zhang D, Wang W, et al. A novel coronavirus from patients with pneumonia in China, 2019. N Engl J Med. 2020;382(8):727-733. doi:10.1056/NEJMoa2001017

3. Gorbalenya AE, Baker SC, Baric RS, et al. The species severe acute respiratory syndromerelated coronavirus: classifying 2019-nCoV and naming it SARS-CoV-2. Nat Microbiol. 2020;5(4):536-544. doi:10.1038/s41564-020-0695-z

4. Zhou P, Yang X Lou, Wang XG, et al. A pneumonia outbreak associated with a new coronavirus of probable bat origin. Nature. 2020;579(7798):270-273. doi:10.1038/s41586-020-2012-7

5. Wu Z, McGoogan JM. Characteristics of and important lessons from the coronavirus disease 2019 (COVID-19) outbreak in China: summary of a report of 72314 cases from the Chinese Center for Disease Control and Prevention. JAMA - J Am Med Assoc. 2020;323(13):1239-1242. doi:10.1001/jama.2020.2648

6. Wang D, Hu B, Hu C, et al. Clinical characteristics of 138 hospitalized patients with 2019 novel coronavirus-infected pneumonia in Wuhan, China. JAMA - J Am Med Assoc. 2020;323(11):1061-1069. doi:10.1001/jama.2020.1585

7. Guan WJ, Ni ZY, Hu Y, et al. Clinical characteristics of coronavirus disease 2019 in China. N Engl J Med. Published online April 30, 2020. doi:10.1056/NEJMoa2002032

8. Huang C, Wang Y, Li X, et al. Clinical features of patients infected with 2019 novel coronavirus in Wuhan, China. Lancet. 2020;395(10223):497-506. doi:10.1016/S0140$6736(20) 30183-5$ 
9. Li Q, Guan X, Wu P, et al. Early transmission dynamics in Wuhan, China, of novel coronavirus-infected pneumonia. N Engl J Med. 2020;382(13):1199-1207. doi:10.1056/NEJMoa2001316

10. Chen N, Zhou M, Dong X, et al. Epidemiological and clinical characteristics of 99 cases of 2019 novel coronavirus pneumonia in Wuhan, China: a descriptive study. Lancet. 2020;395(10223):507-513. doi:10.1016/S0140-6736(20)30211-7

11. Cao Y, Liu X, Xiong L, Cai K. Imaging and clinical features of patients with 2019 novel coronavirus SARS-CoV-2: A systematic review and meta-analysis. J Med Virol. Published online 2020. doi:10.1002/jmv.25822

12. Wu C, Chen X, Cai Y, et al. Risk factors associated with acute respiratory distress syndrome and death in patients with Coronavirus Disease 2019 pneumonia in Wuhan, China. JAMA Intern Med. Published online 2020. doi:10.1001/jamainternmed.2020.0994

13. Centers for Disease Control and Prevention. Coronavirus Disease 2019 (COVID-19):

Symptoms of Coronavirus. Published 2020. Accessed May 6, 2020.

https://www.cdc.gov/coronavirus/2019-ncov/symptoms-testing/symptoms.html

14. Zhou F, Yu T, Du R, et al. Clinical course and risk factors for mortality of adult inpatients with COVID-19 in Wuhan, China: a retrospective cohort study. Lancet. 2020;395(10229):1054-1062. doi:10.1016/S0140-6736(20)30566-3

15. Pascarella G, Strumia A, Piliego C, et al. COVID-19 diagnosis and management: a comprehensive review. J Intern Med. Published online 2020:joim.13091. 
doi:10.1111/joim.13091

16. Arentz M, Yim E, Klaff L, et al. Characteristics and outcomes of 21 critically ill patients with COVID-19 in Washington State. JAMA - J Am Med Assoc. Published online April 28, 2020. doi:10.1001/jama.2020.4326

17. Du Y, Tu L, Zhu P, et al. Clinical features of 85 fatal cases of COVID-19 from Wuhan: a retrospective observational study. Am J Respir Crit Care Med. Published online April 3, 2020. doi:10.1164/rccm.202003-05430C

18. Tay MZ, Poh CM, Rénia L, MacAry PA, Ng LFP. The trinity of COVID-19: immunity, inflammation and intervention. Nat Rev Immunol. Published online 2020:1-12. doi:10.1038/s41577-020-0311-8

19. Zou L, Ruan F, Huang M, et al. SARS-CoV-2 viral load in upper respiratory specimens of infected patients. N Engl J Med. 2020;382(12):1177-1179. doi:10.1056/NEJMc2001737

20. Long Q-X, Liu B-Z, Deng H-J, et al. Antibody responses to SARS-CoV-2 in patients with COVID-19. Nat Med. Published online 2020:1-4. doi:10.1038/s41591-020-0897-1

21. Zhao J, Yuan $\mathrm{Q}$, Wang $\mathrm{H}$, et al. Antibody responses to SARS-CoV-2 in patients of novel coronavirus disease 2019. Clin Infect Dis. Published online March 28, 2020. doi:10.1093/cid/ciaa344

22. Jin $\mathrm{Y}$, Wang $M$, Zuo Z, et al. Diagnostic value and dynamic variance of serum antibody in coronavirus disease 2019. Int J Infect Dis. 2020;94:49-52. doi:10.1016/j.ijid.2020.03.065

23. Zhao R, Li M, Song H, et al. Early detection of SARS-CoV-2 antibodies in COVID-19 
patients as a serologic marker of infection. Clin Infect Dis. Published online May 1, 2020. doi:10.1093/cid/ciaa523

24. Liu W, Liu L, Kou G, et al. Evaluation of nucleocapsid and spike protein-based ELISAs for detecting antibodies against SARS-CoV-2. J Clin Microbiol. Published online March 30, 2020. doi:10.1128/JCM.00461-20

25. Okba NMA, Müller MA, Li W, et al. Severe acute respiratory syndrome coronavirus 2specific antibody responses in coronavirus disease 2019 patients. Emerg Infect Dis. 2020;26(7). doi:10.3201/eid2607.200841

26. To KKW, Tsang OTY, Leung WS, et al. Temporal profiles of viral load in posterior oropharyngeal saliva samples and serum antibody responses during infection by SARSCoV-2: an observational cohort study. Lancet Infect Dis. 2020;20(5):565-574. doi:10.1016/S1473-3099(20)30196-1

27. Li G, Chen X, Xu A. Profile of specific antibodies to the SARS-associated coronavirus. $N$ Engl J Med. 2003;349(5):508-509. doi:10.1056/NEJM200307313490520

28. Woo PCY, Lau SKP, Wong BHL, et al. Longitudinal profile of immunoglobulin G (IgG), IgM, and IgA antibodies against the severe acute respiratory syndrome (SARS) coronavirus nucleocapsid protein in patients with pneumonia due to the SARS coronavirus. Clin Diagn Lab Immunol. 2004;11(4):665-668. doi:10.1128/CDLI.11.4.665-668.2004

29. Wu LP, Wang NC, Chang YH, et al. Duration of antibody responses after severe acute respiratory syndrome. Emerg Infect Dis. 2007;13(10):1562-1564. 
doi:10.3201/eid1310.070576

30. Xiang F, Wang $\mathrm{X}$, He X, et al. Antibody detection and dynamic characteristics in patients with COVID-19. Clin Infect Dis. Published online April 19, 2020. doi:10.1093/cid/ciaa461

31. Krammer F, Simon V. Serology assays to manage COVID-19. Science.

2020;368(6495):1060-1061. doi:10.1126/science.abc1227

32. Whitman JD, Hiatt J, Mowery CT, et al. Test performance evaluation of SARS-CoV-2 serological assays. medRxiv. Published online 2020:2020.04.25.20074856.

doi:10.1101/2020.04.25.20074856

33. Theel ES, Harring J, Hilgart H, Granger D. Performance Characteristics of Four HighThroughput Immunoassays for Detection of IgG Antibodies against SARS-CoV-2. J Clin Microbiol. Published online June 2020. doi:10.1128/JCM.01243-20

34. Robbiani DF, Gaebler C, Muecksch F, et al. Convergent antibody responses to SARS-CoV-2 in convalescent individuals. Nature. Published online 2020. doi:10.1038/s41586-0202456-9

35. Suthar MS, Zimmerman MG, Kauffman RC, et al. Rapid Generation of Neutralizing Antibody Responses in COVID-19 Patients. Cell Reports Med. 2020;1(3):100040. doi:10.1016/j.xcrm.2020.100040

36. Yasui F, Kai C, Kitabatake M, et al. Prior Immunization with Severe Acute Respiratory Syndrome (SARS)-Associated Coronavirus (SARS-CoV) Nucleocapsid Protein Causes Severe Pneumonia in Mice Infected with SARS-CoV. J Immunol. 2008;181(9):6337-6348. 
doi:10.4049/jimmunol.181.9.6337

37. Jaume M, Yip MS, Cheung CY, et al. Anti-Severe Acute Respiratory Syndrome Coronavirus Spike Antibodies Trigger Infection of Human Immune Cells via a $\mathrm{pH}$ - and Cysteine Protease-Independent Fc R Pathway. J Virol. 2011;85(20):10582-10597. doi:10.1128/jvi.00671-11

38. Bolles M, Deming D, Long K, et al. A Double-Inactivated Severe Acute Respiratory Syndrome Coronavirus Vaccine Provides Incomplete Protection in Mice and Induces Increased Eosinophilic Proinflammatory Pulmonary Response upon Challenge. J Virol. 2011;85(23):12201-12215. doi:10.1128/jvi.06048-11

39. Liu L, Wei $Q$, Lin $Q$, et al. Anti-spike IgG causes severe acute lung injury by skewing macrophage responses during acute SARS-CoV infection. JCl insight. 2019;4(4). doi:10.1172/jci.insight.123158

40. Iwasaki A, Yang Y. The potential danger of suboptimal antibody responses in COVID-19. Nat Rev Immunol. 2020;20(6):339-341. doi:10.1038/s41577-020-0321-6

41. Nilles EJ, Karlson EW, Norman M, et al. Evaluation of two commercial and two noncommercial immunoassays for the detection of prior infection to SARS-CoV-2. medRxiv. Published online 2020:2020.06.24.20139006. doi:10.1101/2020.06.24.20139006 
A

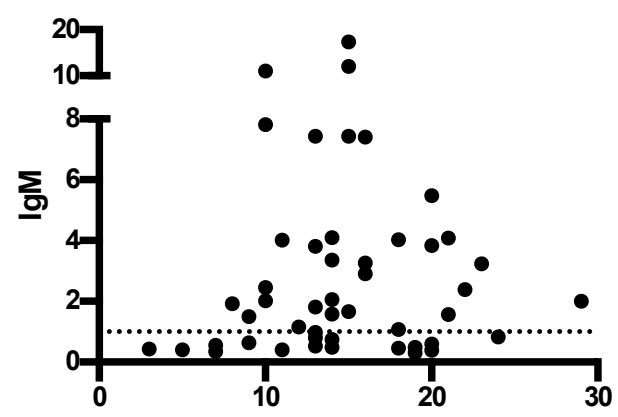

C

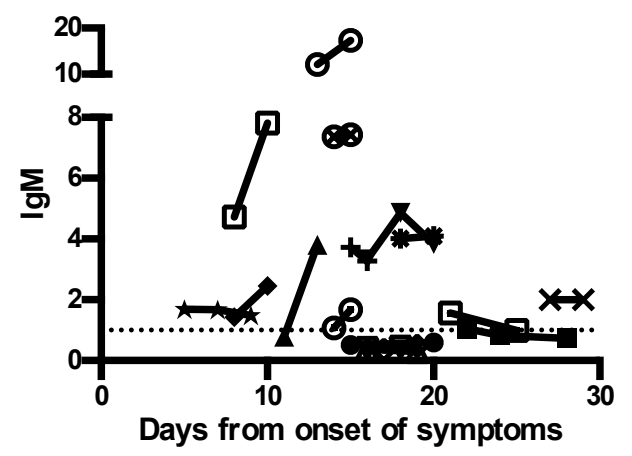

B

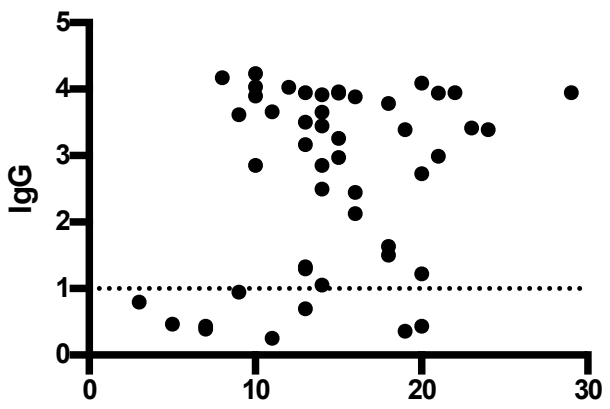

D

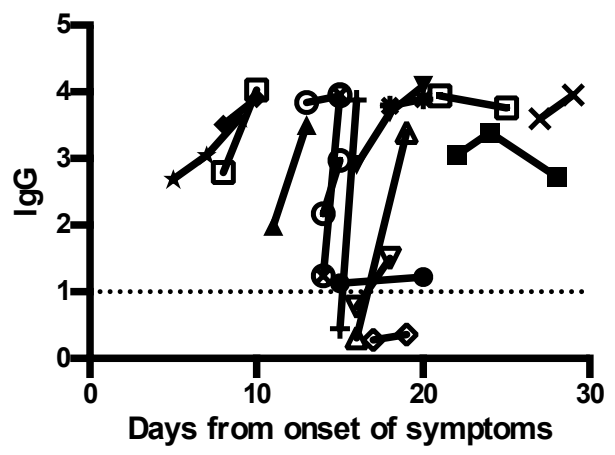

Figure 1. IgM and IgG antibody responses over the course of infection. A, IgM for individual patients relative to reported onset of symptoms. The sample from the latest time point is shown for individuals with more than one sample. B, IgG for individual patients relative to reported onset of symptoms. The sample from the latest time point is shown for individuals with more than one sample. C, IgM levels for patients with serial samples relative to reported onset of symptoms. Measurements from the same patient are drawn connected by a line. D, IgG levels for patients with serial samples relative to reported onset of symptoms. Measurements from the same patient are drawn connected by a line. The reference range is negative $<0.820$, borderline 0.820-0.999, positive $>0.999$. 
A

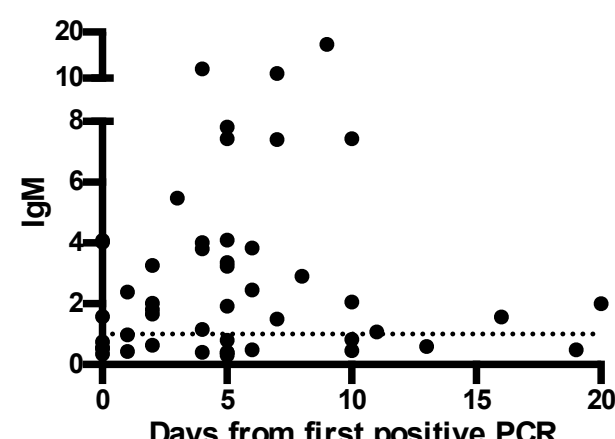

C

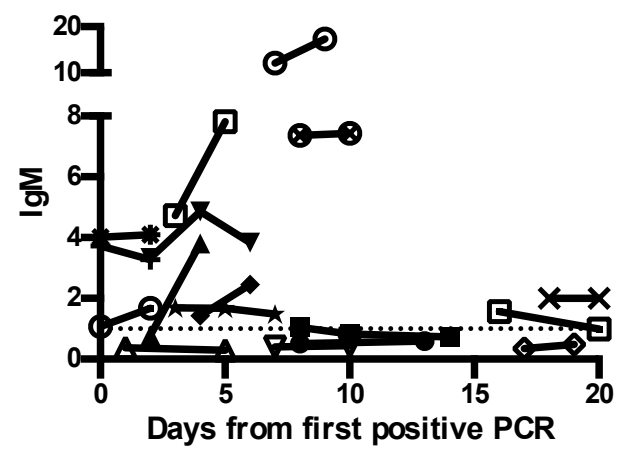

B

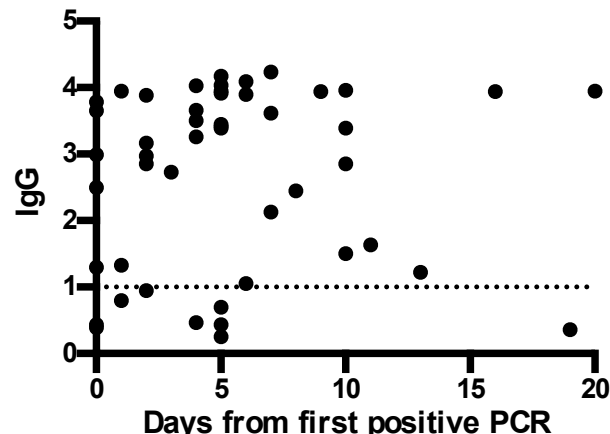

D

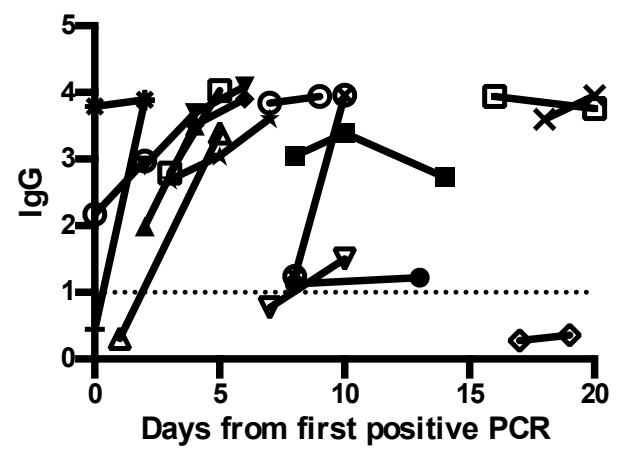

Figure 2. IgM and IgG antibody responses relative to positive RT-PCR. A, IgM for individual patients relative to the first positive COVID RT-PCR. The sample from the latest time point is shown for individuals with more than one sample. B, IgG for individual patients relative to the first positive COVID RT-PCR. The sample from the latest time point is shown for individuals with more than one sample. C, IgM levels for patients with serial samples relative to the first positive COVID RT-PCR. Measurements from the same patient are drawn connected by a line. D, IgG levels for patients with serial samples relative to the first positive COVID RT-PCR. Measurements from the same patient are drawn connected by a line. The reference range is negative $<0.820$, borderline 0.820-0.999, positive $>0.999$. 


\begin{tabular}{|c|c|}
\hline Characteristic & $N=48$ \\
\hline Median age (IQR) -- yr. & $61(49-69)$ \\
\hline Female sex -- no. (\%) & $25(52)$ \\
\hline \multicolumn{2}{|l|}{ Race/ethnicity -- no. (\%) } \\
\hline Black or African American & $16(48)$ \\
\hline Hispanic or Latino & $14(29)$ \\
\hline White, non-Hispanic & $13(27)$ \\
\hline Asian & $1(2)$ \\
\hline Other or not specified & $4(8)$ \\
\hline \multicolumn{2}{|l|}{ Comorbidities -- no. (\%) } \\
\hline Cardiovascular disease & $7(15)$ \\
\hline Cerebrovascular disease & $2(4)$ \\
\hline Chronic lung disease & $8(17)$ \\
\hline Diabetes & $13(27)$ \\
\hline Hypertension & $23(48)$ \\
\hline Malignancy* & $14(29)$ \\
\hline Other chronic illness & $28(58)$ \\
\hline None & $4(8)$ \\
\hline \multicolumn{2}{|l|}{ Clinical criteria -- no. (\%)† } \\
\hline Chills & $10(21)$ \\
\hline Cough & $39(81)$ \\
\hline Fever & $35(73)$ \\
\hline Headache & $10(21)$ \\
\hline Muscle pain & $13(27)$ \\
\hline New loss of taste or smell & $5(10)$ \\
\hline Shortness of breath & $28(58)$ \\
\hline Sore throat & $8(17)$ \\
\hline Repeated shaking with chills & $2(4)$ \\
\hline Other & $29(60)$ \\
\hline Gastrointestinal symptoms $\ddagger$ & $20(42)$ \\
\hline Cardiac symptoms§ & $5(10)$ \\
\hline \multicolumn{2}{|l|}{ *Prior or current malignancy } \\
\hline \multicolumn{2}{|c|}{ +Clinical criteria based on the CDC case definition of COVID-19 } \\
\hline \multicolumn{2}{|c|}{$\mp$ Nausea, vomiting, diarrhea, abdominal pain and/or anorexia } \\
\hline SChest pain or chest tightness & \\
\hline
\end{tabular}




\begin{tabular}{|c|c|c|c|c|c|c|c|c|}
\hline \begin{tabular}{|c} 
Age \\
range \\
(years) \\
sex
\end{tabular} & $\begin{array}{l}\text { Underlying } \\
\text { condition(s) }\end{array}$ & $\begin{array}{c}\text { Clinical } \\
\text { presentation }\end{array}$ & $\begin{array}{c}\text { Time since } \\
\text { symptom } \\
\text { onset } \\
\text { (days) }\end{array}$ & $\begin{array}{l}\text { Immuno- } \\
\text { suppressive } \\
\text { medications }\end{array}$ & \begin{tabular}{|c|} 
Hospital \\
length of \\
stay \\
(days)
\end{tabular} & $\begin{array}{c}\text { Intubation } \\
(\mathrm{Y} / \mathrm{N})\end{array}$ & $\begin{array}{c}\text { Outcome } \\
\text { at } \\
\text { discharge }\end{array}$ & $\begin{array}{c}\text { Possible } \\
\text { explanation of lack } \\
\text { of antibody } \\
\text { response }\end{array}$ \\
\hline $\begin{array}{c}51-60 \\
M\end{array}$ & $\begin{array}{c}\text { HIV (CD4 count } \\
593)\end{array}$ & $\begin{array}{l}\text { Cough, } \\
\text { dyspnea }\end{array}$ & 3 & None & 4 & $\mathrm{~N}$ & Alive & Early in disease \\
\hline $\begin{array}{c}61-70 \\
F\end{array}$ & $\begin{array}{c}\text { Diabetes, atrial } \\
\text { fibrillation, } \\
\text { meningioma }\end{array}$ & Cough, fever & 5 & Dexamethasone & 30 & $\mathrm{Y}$ & Alive & Early in disease \\
\hline $\begin{array}{c}41-50 \\
M\end{array}$ & $\begin{array}{c}\text { Hyperlipidemia, } \\
\text { hypertension }\end{array}$ & $\begin{array}{l}\text { Cough, fever, } \\
\text { myalgia, } \\
\text { headache, } \\
\text { anosmia, } \\
\text { rhinorrhea, } \\
\text { diarrhea }\end{array}$ & 7 & None & 0 & $\mathrm{~N}$ & Alive & Early in disease \\
\hline $\begin{array}{c}71-80 \\
F\end{array}$ & $\begin{array}{c}\text { Diabetes, } \\
\text { hyperlipidemia, } \\
\text { hypertension }\end{array}$ & $\begin{array}{l}\text { Cough, } \\
\text { dyspnea, } \\
\text { fever, sore } \\
\text { throat, } \\
\text { anosmia }\end{array}$ & 7 & None & 13 & $\mathrm{~N}$ & Alive & Early in disease \\
\hline $\begin{array}{c}61-70 \\
F\end{array}$ & $\begin{array}{l}\text { Diabetes, } \\
\text { hypertension, } \\
\text { prior colon } \\
\text { cancer }\end{array}$ & $\begin{array}{c}\text { Fever, fatigue, } \\
\text { anorexia }\end{array}$ & 9 & None & 20 & Y & Alive & Early in disease \\
\hline $\begin{array}{c}51-60 \\
F\end{array}$ & $\begin{array}{c}\text { Systemic } \\
\text { scleroderma }\end{array}$ & $\begin{array}{l}\text { Cough, } \\
\text { dyspnea, } \\
\text { fever, chills, } \\
\text { sore throat, } \\
\text { nausea, } \\
\text { vomiting }\end{array}$ & 11 & $\begin{array}{c}\text { Mycophenolate } \\
\text { mofetil }\end{array}$ & 32 & Y & Deceased & Immunosuppressed \\
\hline $\begin{array}{c}81-90 \\
F\end{array}$ & \begin{tabular}{|c|} 
Hypertension, \\
hyperlipidemia, \\
monocytosis \\
with TET2 \\
mutation
\end{tabular} & $\begin{array}{l}\text { Muscle pain, } \\
\text { vomiting, } \\
\text { anorexia, } \\
\text { rhinorrhea }\end{array}$ & 13 & None & 32 & Y & Alive & Early in disease \\
\hline $\begin{array}{c}61-70 \\
M\end{array}$ & $\begin{array}{c}\text { Acute } \\
\text { Iymphoblastic } \\
\text { leukemia }\end{array}$ & $\begin{array}{c}\text { Cough, } \\
\text { headache }\end{array}$ & 19 & \begin{tabular}{|c|} 
Rituximab, \\
cyclophosphamide, \\
vincristine, \\
daunorubicin, \\
prednisone, $\mathrm{PEG}$ \\
asparaginase
\end{tabular} & 73 & Y & Alive & Immunosuppressed \\
\hline $\begin{array}{c}71-80 \\
F\end{array}$ & $\begin{array}{c}\text { Acute myeloid } \\
\text { leukemia }\end{array}$ & Fever, fatigue & 20 & $\begin{array}{l}\text { Azacytidine, } \\
\text { venetoclax }\end{array}$ & 24 & $\mathrm{~N}$ & Alive & Immunosuppressed \\
\hline
\end{tabular}


Table 3. Correlation of SARS-CoV-2 IgM responses to other laboratory findings

\begin{tabular}{|c|c|c|c|c|}
\hline Result* & $\begin{array}{l}\text { IgM negative } \\
\text { median (IQR) }\end{array}$ & $\begin{array}{l}\text { IgM positive } \\
\text { median (IQR) }\end{array}$ & $\begin{array}{c}\text { Mann-Whitney } \\
\text { p value }\end{array}$ & $\begin{array}{c}\text { Bonferroni adjusted } \\
\text { p value }\end{array}$ \\
\hline $\operatorname{ALT}(\mathrm{U} / \mathrm{mL})$ & $22(17,35)$ & $42(21,61)$ & 0.003 & 0.029 \\
\hline AST (U/mL) & $25(16,52)$ & $46(33,85)$ & 0.083 & 0.751 \\
\hline D-dimer (ng/mL) & $854(540,1855)$ & $1990(893,3900)$ & 0.065 & 0.587 \\
\hline Ferritin (ug/dL) & $606(450,1103)$ & $1309(742,1712)$ & 0.062 & 0.554 \\
\hline Globulin (g/dL) & $3(3,3)$ & $3.4(3.1,3.8)$ & 0.017 & 0.149 \\
\hline $\begin{array}{l}\text { Lymphocyte count } \\
\text { (K/uL) }\end{array}$ & $1.1(0.7,1.6)$ & $1(0.8,1.7)$ & 0.935 & 1.000 \\
\hline Platelet count (K/uL) & $223(161,247)$ & $264(190,354)$ & 0.278 & 1.000 \\
\hline Procalcitonin $(\mathrm{ng} / \mathrm{mL})$ & $0.17(0.08,0.42)$ & $0.25(0.13,0.59)$ & 0.368 & 1.000 \\
\hline Troponin T (ng/L) & $12(8,23)$ & $9(6,22)$ & 0.558 & 1.000 \\
\hline
\end{tabular}

Table 4. Correlation of SARS-CoV-2 IgG responses to other laboratory findings

\begin{tabular}{|c|c|c|c|c|}
\hline Result* & $\begin{array}{l}\text { IgG negative } \\
\text { median (IQR) }\end{array}$ & $\begin{array}{l}\text { IgG positive } \\
\text { median (IQR) }\end{array}$ & $\begin{array}{c}\text { Mann-Whitney } \\
\text { p value }\end{array}$ & $\begin{array}{c}\text { Bonferroni adjusted } \\
\text { p value }\end{array}$ \\
\hline $\operatorname{ALT}(\mathrm{U} / \mathrm{mL})$ & $22(19,34)$ & $34(20,61)$ & 0.082 & 0.742 \\
\hline AST (U/mL) & $25(18,40)$ & $44(27,76)$ & 0.580 & 1.000 \\
\hline D-dimer (ng/mL) & $775(501,1815)$ & $1840(865,3637)$ & 0.049 & 0.440 \\
\hline Ferritin (ug/dL) & $616(351,1153)$ & $1228(588,1689)$ & 0.345 & 1.000 \\
\hline Globulin (g/dL) & $2.8(2.7,3.3)$ & $3.4(2.8,3.6)$ & 0.100 & 0.900 \\
\hline $\begin{array}{l}\text { Lymphocyte count } \\
\text { (K/uL) }\end{array}$ & $1.1(0.7,1.3)$ & $1.1(0.8,1.7)$ & 0.397 & 1.000 \\
\hline Platelet count (K/UL) & $210(145,242)$ & $239(190,348)$ & 0.174 & 1.000 \\
\hline Procalcitonin $(\mathrm{ng} / \mathrm{mL})$ & $0.26(0.09,0.61)$ & $0.25(0.1,0.5)$ & 0.962 & 1.000 \\
\hline Troponin T (ng/L) & $12(10,19)$ & $9(6,24)$ & 0.576 & 1.000 \\
\hline
\end{tabular}

